\title{
WALT WHITMAN, WILLIAM JAMES, AND PRAGMATIST AESTHETICS
}

\author{
Raphael C. Allison
}

William James begins his 1899 essay "On a Certain Blindness in $\mathrm{Hu}$ man Beings" by claiming that "our judgments concerning the worth of things, big or little, depend on the feelings the things arouse in us." The essay goes on to argue that human beings are susceptible to a debilitating self-absorption by which we become blind "to the feelings of creatures and people different from ourselves." As others are similarly blinded, individualism threatens social cohesion. "Hence the stupidity and injustice of our opinions," he says, "so far as they deal with the significance of alien lives." For James, the road back to sight and society is through the faculty of familiarizing "feeling":

Where we judge a thing to be precious in consequence of the idea we frame of it, this is only because the idea is itself associated already with a feeling. If we were all radically feelingless, and if ideas were the only things our mind could entertain, we should lose all our likes and dislikes at a stroke.

James is articulating the importance of the aesthetic-defined here as the felt qualities of experience-for creating a basis for social relations. Without such felt likes or dislikes, people would remain "too much absorbed in their own vital secrets" to care about their fellow citizens. ${ }^{1}$

James finds such an aesthetic ideal in Walt Whitman, a poet who James says "abolishes the usual distinctions, brings all conventionalisms into solution, and loves and celebrates hardly any human attributes save those elementary ones common to all members of the race."2 James values Whitman for this ability to overstep logical categories and create mergers where there were once separations. By such unifying aesthetic action - which is revealed in his poetry, prose, notebooks, and orationsWhitman can "change the usual standards of human value" 3 through a generosity of feeling that facilitates communication between not only people but elements of American culture as well. Where individuals once languished in private consternation, Whitman's aesthetic allows for the merging of "alien lives." This essay will provide an overview of James's aesthetics of communication, a reading of Whitman's poem "Song of the Broad-Axe" through the lens of James's aesthetic pragma- 
tism, and an evaluation of Whitman's place in the pragmatist tradition, concluding with a brief sketch of his own ideas of aesthetic action. By understanding Whitman's role in shaping James's thought, the importance of the aesthetic for pragmatism itself is also made clear.

The official philosophical discourse of the aesthetic did not appeal to James: "The aesthetic principles are at bottom such axioms," he says in Principles of Psychology, "as that a note sounds good with its third and fifth, or that potatoes need salt." But James admits in the next breath of the socializing possibilities of the aesthetic in its powers of relation. ${ }^{4}$ Speaking on "Aesthetic and Moral Principles," James says:

Instinctively, one judges everything differently, according as it pertains to one's self or to someone else. Empirically one notices that everybody else does the same. But little by little there dawns in one the judgment "nothing can be right for me which would not be right for another similarly placed"; or "the fulfillment of my desires is intrinsically no more imperative than that of anyone else's." 5

Making no distinction here between the aesthetic and moral, James highlights their mutual quality of social normalizing: one's own predilections become imbricated with others' and are thus thrown into relief once one realizes, in ethical terms, that what is good for oneself is good for everybody. In aesthetic terms this implies that judgments of taste lead to the recognition of a faculty in common with others rather than a personally transcendent consciousness - the kind of "axiom" he so dislikes. The "blindness" or isolation of human beings is cured by an aesthetic jolt of feeling.

For James the aesthetic is, far from its common association with isolation and "distance," a kind of holistic pluralism - a faculty for drawing together, uniting, and creating equivalence between distinct entities, be they "big or little." "There is the only kind of beauty there ever was," he says, "the real and the ideal in one." Whitman's unique form of "abolishing the usual distinctions" to unite the supposedly sundered real and ideal leads James, in his 1907 book Pragmatism, to his most comprehensive analysis of Whitman, which focuses on "To You"-originally published in the 1856 Leaves of Grass as "Poem of You, Whoever You Are"- that takes the form of an apostrophe to the second person pronoun. James explains that the "you" of the poem may be read as representative of one's core self or essential being, the "cosmic" you, "the you of quietism, of indifferentism." This is the stable and stoic "you" that one can always rely and fall back upon. James calls this first you the "monistic" you. He indicates an alternative to monism, however, a "you" that may also imply one's "better possibilities," what he calls "the specific redemptive effects even of your failures, upon yourself or others." This is the "you" of future modification. It is contrary to the stoic you because it considers itself able to be changed and improved. 
James calls this the "pluralistic" you. ${ }^{7}$ These two "you"s correspond to the "blind" and the "feeling" human beings discussed above.

By opposing these two modes of perception-that is, monism and pluralism-James reinforces various familiar dichotomies: unity/pluralism; past/future; transcendentalism/descendentalism; optimism/pessimism. James's decision, however, is to escape such Manichaeism by invoking a third, "pragmatic" approach, one he finds embodied in Whitman's sense of "you": "Midway between the two there stands what may be called the doctrine of meliorism." 8 This is not simply the belief that with human effort the world will improve-though it does offer optimism about human improvement. Rather, pragmatic meliorism is a tool for retaining the philosophical home-comforts of monism and cohesion while simultaneously offering a more inclusive, future-oriented pluralism. Pragmatic meliorism says that one may fall back upon the monistic "you" as well as improve and re-create the second, pluralistic "you," using both and sacrificing neither. In this way, aesthetics may be removed, toned, and "unified" - all qualities often associated with aesthetic experience-while also serving as a functional, ordinary part of life that underlies social existence. When James outlines his two reading strategies for the poem "To You," he says, in Whitman's spirit, that they are both "useful."

Whitman emerges from James's reading neither as a monist or a pluralist, but as a Jamesian meliorist who fosters essence while simultaneously creating new possibilities - and as one who "abolishes the usual distinctions" between the aesthetic and the social, the eternal and the immediate, the real and the ideal, thus allowing them to "merge." Throughout Leaves of Grass Whitman appeals to the unchanging, Platonic "soul" and fears what he calls in one poem "the terrible doubt of appearances." But he also dotes on the particularities of the human form, "Of physiology from top to toe." ${ }^{10}$ Whitman's poetry helps James create such a reading strategy by offering contrasting-but not conflicting - visions of American life and identity, in which one can appeal to a non-material world of pure form while simultaneously trailing one's fingers through the "scented herbage" of one's breast. Earlier in Pragmatism, capturing the oxymoronic nature of a philosophy at once transcendental and descendental, James coins an impossible term, as appropriate for Whitman as for himself: "pluralistic monism." ${ }^{11}$ For Pragmatism, this melioristic attitude in which stability can coexist with change helps James to mollify an audience perhaps threatened by such a de-centered and radically contingent philosophy.

James's form of meliorism arises clearly in Whitman's "Song of the Broad-Axe," a poem first published as "Broad-Axe Poem" in the second (1856) edition of Leaves of Grass. ${ }^{12}$ The axe was an important symbol of nationhood for Whitman- "Make it the American emblem preferent to the eagle," he says of it in a notebook fragment ${ }^{13}$-and 
reveals itself as an almost overdetermined object of scrutiny from the outset. For instance, the poem opens with a strong doubling motif, in which the axe becomes the site of multiple possibilities while retaining a symbolic strength of singularity. The central image of the axe as something "to be leaned and to lean on" captures the double nature of this melioristic linguistic project, to create something both dependable and functionary, something that offers stability while also creating advantages of change. The opening lines offer a compact formalism rare in Whitman's poetry. There is a loping, trochaic chant and a loose endrhyme that repeats itself six times (a record in Leaves of Grass) and suggests rigorous aesthetic stasis. The trochees also imitate the call and response of an axe echoing in the forest. The short stanza earns an adjective rarely applied to Whitman's poetry: "chiseled."

Weapon shapely, naked, wan,

Head from the mother's bowels drawn,

Wooded flesh and metal bone, limb only one and lip only one,

Gray-blue leaf by red-heat grown, helve produced from a little seed sown,

Resting the grass amid and upon,

To be leaned and to lean on. ${ }^{14}$

These lines initiate a doubling motif that suggests Jamesian pluralism: on the one hand the axe has the focus and attention of a Yeatsian symbol, though as a human-made object it defies a sublime or Romantic symbolicity; it is "to be leaned," but it is also "to lean on," not simply a tool for work but an instrument of leisure as well; the axe is half vegetable - "wooded flesh" - and half mineral_-"metal bone"; it is an inanimate object, of course, yet it has apparently been born, in some mythopoetic way, the "head from the mother's bowels drawn"; it's got an animal's "limb" and "lip," but in the next line its provenance is revealed: the "red heat" of the blacksmith and the "little seed" sown in the forest are its material parents.

The penultimate line offers the most thematically significant grammatical construction: "resting the grass amid and upon." The sense of doubling is here represented in the actual syntax of this line, and the reader is drawn into constructing the syntax of the poem. It is as if Whitman were submitting two prepositional possibilities for the axe's whereabouts: "amid" the grass would suffice if we were thinking on a horizontal plane, and "upon" the grass if we were thinking on a vertical one. But the reader is offered both alternatives, for his or her choosing, put after the phrase. The reader is asked to imagine a space between the words "resting" and "the grass," then given the task of repositioning the words: the axe is "resting amid the grass" and "resting upon the grass." Whitman lets us have it both ways, and the reader is put into the active position of having to make a syntactical decision. This is an essential part of Whitman's meliorist aesthetic: it inculcates a sense of real par- 
ticipation in the reader and allows him or her to actually enter the poem, refashion the words, and see the language as living and subject to change; it also helps to abolish those "conventional distinctions," like that between writer and reader, that James would like to eradicate in the service of community life.

After this birth of the axe, the poem dilates into a catalogue of the axe's creation from Sections 2 through 8, with the suggestion that the axe be used to break with the European past. But in Section 9, the poem begins to tighten again, signified by the phrase "the axe leaps!" As it leaps, the melioristic doubling at the beginning of the poem gains its significance: the axe's function as a tool is deepened by its significance as an aesthetic object. Just as the axe is "amid and upon" the grass, and just as it is half wood/half metal, it is also half tool, half aesthetic. "The solid forest gives fluid utterances," cries Whitman, as if the axe is actually shaping language itself. His line "They tumble forth, they rise and form," can be read as the act of poetic creation. So begins the long crescendo to the resounding refrain of the poem, in which, finally, the idea of "shape" is introduced: "The shapes arise! Shapes of Democracy!" These "shapes" are at first presented as the objects of daily life: "shapes of doors giving many exits and entrances," "the shape of the step-ladder for the convicted," "the shape of the liquor-bar," the shape of "the shamed and angry stairs trod by sneaking footsteps," and so on. Most importantly, however, they are "shapes," forms that are carved into existence by the axe with all the aesthetic force of a painting or a statue. The axe is creating "fluid utterances," what the poet sees as a graceful new language that builds both beauty and society simultaneously.

A number of observations have been made: first, that "Song of the Broad-Axe" creates a sense of doubling, a fact that suggests Jamesian pluralism; second, that this doubling is part of the poem's actual form, as the chiseled first stanza fans out into loose catalogue and back into a tighter formalism; and third, that it asks the reader to participate in its composition by offering a correctable syntax. These strands can be knotted together by investigating Whitman's use of the word "shape." Whitman consistently associates shape with literary language. It appears in a poem first published in the 1860 edition of Leaves of Grass, "Starting from Paumanok." In this poem he calls out to "Dead poets, philosophs, priests, / Martyrs, artists, inventors, governments long since, / Language-shapers on other shores." 15 Here, too, Whitman's concern is with the doubled nature of reality, what he calls the "Melange mine own, the unseen and the seen." So "shape" is associated with languagethe "utterances" of the broad-axe-and specifically literary language.

In his 1871 essay Democratic Vistas, shape is the metaphor repeatedly used to describe the new American literary aesthetic and its possible effects: "it may be, a single new thought, imagination, abstract principle, even literary style, fit for the time, put in shape by some great 
literatus ... may duly cause changes"; ${ }^{16}$ later he says that literature "shapes the character of church and school"; Lincoln's "of the people, by the people, for the people," says Whitman, is "a formula whose verbal shape is homely wit." 17 This use of "shape" to designate a kind of aesthetic of language is upheld throughout the notebooks, in his 1855 preface, and in his later poetry. It is one of Whitman's unconscious verbal tics that charges the word with significance.

The broad-axe, then-what he calls in the first line the "weapon shapely, naked, wan"-is inherently democratic and inherently literary, a concatenation of the social and the aesthetic. Whitman's democracy is to be realized through instruments like the axe, a double force that combines the workaday functionalism that generates America's literal and physical bulk with the "shapely" qualities of artistic expression. Just like the "you" of his earlier poem, here "shape" becomes a portmanteau word, projecting a series of possible meanings, none conclusive: it stands for physical buildings, the idea of democracy, and the new formations of language. Thus democracy is itself an object of aesthetic appreciation; the shapes of democracy are aesthetically constituted forces.

Of course, this formula may be reversed, as the axe itself suggests. In that case, the aesthetics of everyday living become part of the aesthetics of art. The everyday is simply aestheticized, but, conversely, art is made more everyday, thus conflating the space between "art" and "life." As the poem moves from a rigorous formalism to the loose and baggy monster of a middle, back into a more formal pose at the end, it asks readers to consider the cohabitation of refined, formalized, highly shaped art and the sprawling, multiplying, growing, future-oriented land in which this art is picking its way. The broad axe is an agent of linguistic transformation, re-shaping an established but incompatible language for its democratic mission. James's appreciation of Whitman's ability to "abolish distinctions" is born out in Whitman's ability to unite the aesthetic and the social discourses, the "ideal and the real," as James says, under one roof.

Whitman not only reflects such a pragmatist ideology in his meliorist aesthetics, he helps to create one as well. His ability to see aesthetics as something that actually helps shape communities is entirely Jamesian; and, inversely, James takes from Whitman an understanding that the abolition of distinctions and conventions - whether they be philosophical, interpersonal, or cultural - is mediated through the intensity of feeling rather than an abstract conceptual framework. Whitman also anticipates John Dewey's insistence that aesthetic experience is not just something good for flavor or character, but rather a fundamental ingredient for a developing American society. Whereas Dewey may be more direct- "works of art are the only media of complete unhindered communication between man and man that can occur in a world full of gulfs and walls that limit community of experience" 18 - Whitman underscores 
this point repeatedly in his work. In the preface to the 1855 edition, he says that "the United States themselves are essentially the greatest poem" and that "the poets of the kosmos . . . are of use." 19 Democratic Vistas declares that "great literature penetrates all, gives hue to all," and says that "a few first-class poets, philosophs, and authors, have substantially settled and given status to the entire religion, education, law, sociology, \&c., of the hitherto civilized world, by tinging and often creating the atmospheres out of which they have arisen. . .".20

While there has been substantial discussion of the way in which Whitman forecasts pragmatism in general, his peculiar blend of pragmatism with aesthetics is what most significantly binds him to a pragmatist tradition. Though C. S. Peirce once wrote in a notebook that "Emerson is at least not sensual but Walt Whitman has no good trait to be mentioned,"21 later pragmatists and scholars in general have not shared Peirce's feelings. As far back as 1955 Gay Wilson Allen, who also wrote one of the first major studies of William James, asked "what was [Whitman's] theory of 'Democracy' but the forerunner of William James's 'Pluralism' and John Dewey's 'Pragmatism'?"22 The historian James Livingston keenly perceives Whitman's prescience for American philosophy, and specifically the pragmatism of William James: "[James] insists that Whitman wrote the history of the future James himself would inhabit." ${ }^{23}$ Alan Trachtenberg has written two essays that explore the effects of Whitman on James, claiming that "a roll call of Whitmanian modernists includes the most prominent names . . . [including] the provocateurs and agitators who prepared a sympathetic climate for aesthetic change," and he includes William James on the list. In his essay on the political economy of developing urban landscapes, Trachtenberg claims that "without saying so, James portrays a Whitman who intuits pragmatism, the view that truth is partial, subjective, fragmented, scattered." 24 And Kenneth Burke, a quasi-pragmatist himself, says that James, Whitman, and Emerson created "the three most well-rounded . . . frames of acceptance in American literature." 25 By "frame of acceptance" Burke means a symbolic theodicy or strategy to account for evila way of linking James and Whitman that seems correct. ${ }^{26}$

Dewey explicitly confessed a significant debt to Whitman: "Democracy will come into its own, for democracy is a name for a life of free and enriching communion," he writes in the final paragraph of The Public and Its Problems. "It had its seer in Walt Whitman. It will have its consummation when free social inquiry is indissolubly wedded to the art of full and moving communication." 27 Just as for James, for Dewey it is the communicability of Whitman's art that makes it significant, and this is the quality he most admires in his own aesthetics. Richard Rorty, the most vocal living pragmatist philosopher, also finds this continuity between Whitman and Dewey in which Whitman's democratic impulse reveals itself in aesthetic terms as "a poetic agon, in which jarring dia- 
lectical discords would be resolved in previously unheard harmonies."28 Both men put hope in "replacing shared knowledge of what is already real with social hope for what might become real"29 - a way of uniting, as James said, "the ideal and the real." 30

For James, the essence of Whitman's aesthetics is his ability to create mergers and find commonalities and irruptions of one thing into another-"solution," "circulation," and "interjection" cited in "On a Certain Blindness" being his central activities. And though it may seem that James accepts Whitman's vagabond persona at face value-James calls him an "ideal tramp" and a "loafer"-he appreciates Whitman for the way in which his poetry both "brings all conventionalisms into solution," as well as, as he later says, "commands us to tolerate, respect, and indulge those whom we see harmlessly interested and happy in their own way." ${ }^{31}$ Whitman accomplishes this through his packing or, as Burke would say, "clustering" of linguistic nodes like "you," "shape," and the broad-axe itself, and by inculcating a sense of feeling or expression so needed to comprehend "alien lives."

For Whitman himself the aesthetic was always the basis of all action. This is the essence of his pragmatism: a commitment to action dictated by a principle of, as Whitman calls it in an important early address, "moral beauty." This address is "Art and Artists," his March, 1851 talk to the Brooklyn Art Union, delivered four years before Leaves of Grass was first published. Here Whitman himself speaks of an aesthetics of pragmatism that is striking for its anticipation of later pragmatist thought. It also offers a way to read Whitmanian pragmatism-and thus Jamesian pragmatism as well — as an aesthetically centered philosophy: "The beautiful artist principle sanctifies that community which is pervaded by it. A halo surrounds forever that nation." 32 By 1851 Whitman had already found the artist's role to be one of building "community" and "nation" through a kind of religious ("halo") communicative binding. He says later, in the same address:

I think of few heroic actions which cannot be traced to the artistic impulse. He who does great deeds, does them from his sensitiveness to moral beauty. Such men are not merely artists, they are artistic material. ${ }^{33}$

Two points are clear in this statement: one, that beauty and action goad each other on, and that beauty initiates rather than relieves one from action; and two, that there is again a kind of categorical destruction in the act of becoming an aesthetic actor - an artist. "Such men are artistic material" - artists leave the task of representation behind, becoming incandescent with their own creative acts. The artist is, for Whitman, he or she who can progress from representation into action, from looking and thinking into doing and moving, combining the "real" and the "ideal." 
Whitman finally associates this kinaesthetic power with an Emersonian shrugging off of the past, in a bit of purple prose near the end of the address:

Talk not so much, then, young artist, of the great old masters, who but painted and chiselled [sic] . . . There is a still better, higher school for him who would kindle his fire with coal from the altar of the loftiest and purest art. It is the school of all grand actions, and grand virtues of heroism. . . . ${ }^{34}$

The abandonment of the "masters" is not gratuitous. It is a deliberate turn from the objects of art to the experience and "grand actions" of the aesthetic. Whitman means that art is a way of life, a mode of being, rather than a bracketed activity one does at school-thus his call for a "school of all grand actions" to counter a more literal scholasticism. It is another example, too, of Whitman's desire to dissolve "conventional distinctions" by inserting the artist into the world at large.

Whitman says in Democratic Vistas that "the literature, songs, esthetics, \&c., of a country are of importance principally because they furnish the materials and suggestions of personality for the women and men of that country, and enforce them in a thousand effective ways." 35 This kind of attitude is only possible if he understands that artistic feeling is part of one's life. Whitman's aesthetics offer the most profound, and perhaps the earliest, understanding of James's pragmatic meliorism, the activity of finding continuity where there was none before-strangers meeting strangers, opening their eyes to the acceptable differences of others and realizing that the work of nation building can constitute an aesthetic activity. This aesthetics of vision is the basis of a healthy society, says James, and he looks to Whitman to exemplify this conviction. Further, this quality of Whitman's work both widens our understanding of the poet himself and illuminates a vital element of pragmatist literature as well. Acknowledging the origins of pragmatism in the work of Whitman helps illuminate the extraordinary complicity not just between Whitman and James, but also between literary and philosophical discourses in America during the late nineteenth century.

\section{New York University}

\section{NOTES}

1 William James, "On a Certain Blindness in Human Beings," in The Writings of William Fames, ed. John J. McDermott (New York: Random House, 1967), 629-630.

2 James, "Blindness," 637.

3 James, "Blindness," 640.

4 James's rejection of aesthetic discourse is often qualified by such an appreciation of aesthetic feeling. For instance, in an 1896 review of Henry R. Marshall's Pain, 
Pleasure, and the Aesthetic, James says that "a single square foot of genuine color is more important to the soul than the reading of all the books on beauty ever composed." See William James, Essays, Comments, Reviews, ed. Frederick H. Burkhardt (Cambridge: Harvard University Press, 1987), 489.

5 William James, The Principles of Psychology (Cambridge: Harvard University Press, 1983), 1264.

6 James, "Blindness," 640.

7 William James, Pragmatism (Cambridge: Hackett Publishing Company, 1981), 125.

8 James, Pragmatism, 128.

9 James, Pragmatism, 125.

10 Whitman, Leaves of Grass (New York: New York University Press, 1965), 1.

11 James, Pragmatism, 11.

12 The version used here is taken from the 1881 edition, found in $L G, 184-195$.

13 Walt Whitman, Notebooks and Unpublished Prose Manuscripts, ed. Edward F. Grier (New York: New York University Press, 1984), 1:299.

14 Whitman, $L G, 184$.

15 Whitman, $L G, 18$. Italics mine.

16 Whitman, Prose Works, 1892, ed. Floyd Stovall (New York: New York University Press, 1964), 2:366. Italics mine.

17 Whitman, $P W, 2: 367,376$. Italics mine.

18 John Dewey, Art as Experience (New York: Perigee Books, 1934), 105.

19 Whitman, $L G, 497$.

20 Whitman, $P W, 2: 366-367$.

21 Quoted in Kenneth Laine Ketner, His Glassy Essence: An Autobiography of Charles Sanders Peirce (Nashville: Vanderbilt University Press, 1998), 155.

22 Gay Wilson Allen, The Solitary Singer: A Critical Biography of Walt Whitman (New York: Macmillan, 1955), 390.

23 James Livingston, Pragmatism and the Political Economy of Cultural Revolution 18501940 (Chapel Hill: University of North Carolina Press, 1994), 170.

24 See Alan Trachtenberg, "Walt Whitman: Precipitant of the Modern," The Cambridge Companion to Walt Whitman, ed. Ezra Greenspan (Cambridge: Cambridge University Press, 1995), 96; and "Whitman's Lesson of the City," Breaking Bounds: Whitman and American Cultural Studies, ed. Betsy Erkkila and Jay Grossman (New York: Oxford University Press, 1996), 166.

25 Kenneth Burke, Attitudes Toward History (Berkeley: University of California Press, 1937), 5. On Burke and pragmatism see Paul Jay, Contingency Blues: The Search for Foundations in American Criticism (Madison: University of Wisconsin Press, 1997).

26 There are other examples: see Daniel S. Malachuk, "Walt Whitman and the Culture of Pragmatism," in Walt Whitman Quarterly Review 17 (Fall 1999), 60-68; Dana 
Brand, “The Escape from Solipsism: William James' Reformulation of Emerson and Whitman," ESQ 118 (1985), 38-48.

27 John Dewey, Fohn Dewey: The Later Works, 1925-53, ed. Jo Ann Boydson (Carbondale: Southern Illinois University Press, 1984), 2:350.

28 Richard Rorty, Achieving Our Country: Leftist Thought in Twentieth-Century America (Cambridge: Harvard University Press, 1998), 24.

\section{Rorty, 15.}

30 Gerald E. Myers says that James underwent a general shift in his career from the dualistic thinking of Principles of Psychology to the "pluralistic monism" of Essays in Radical Empiricism. James's 1904 essay "Does Consciousness Exist?," however, "announced his abandonment of Cartesian dualism or of any ultimate distinction between mind and body, making it clear that he had adopted a provisional dualism in Principles on behalf of a new effort, a textbook in which psychology was at last presented as a natural science." Many factors contributed to this shift; it seems that one of them was the influence of Whitman. See Gerald E. Myers, William fames: His Life and Thought (New Haven: Yale University Press, 1986), 406.

31 James, "Blindness," 644-645.

32 Walt Whitman, The Uncollected Poetry and Prose of Walt Whitman, ed. Emory Holloway (New York: Peter Smith, 1932), 1:244. Abbreviated UPP.

33 Whitman, UPP, 1:246.

34 Whitman, UPP, 1:246.

35 Whitman, $P W, 2: 392$. 